Gordana Čupković, University of Zadar, Croatia

\title{
Wire on Covers
}

\section{Abstract}

This paper analyzes the covers of the weekly newspaper Novosti, on which the current refugee and migrant crisis is depicted with illustrations where various verbal and visual signs recontextualize the motif of barbed and razor wire. The symbolic, satiric, and metaphoric potential of barbed wire is discussed, and its functions in the narrative on migrants are defined. The examples are categorized according to the distinct semantic characteristics of acting on the body and enclosing space, and the presented research model confirms that the pronounced artistic and critical functionality of the motif of barbed wire lies precisely in the potential of establishing an antithesis that is simultaneously also an element of the satirical dialectic and the source of metaphoric interpretations.

Keywords: barbed wire, satire, symbol, conceptual metaphor, semantics

\section{Introduction}

Writing a summary for the history of barbed wire, from the prairies and war trenches to concentration camps, Razac (2009) stops at the control points of contemporary urbanism, where virtual surveillance is implemented through a sophisticated selection of social characteristics, implying a gradual but complete transformation of physical wire into a collection of virtual nodes. However, the circumstances of Western military interventions in the Middle East, the related Middle East wars, and the consequent waves of refugees and migrants have in the meantime revitalized the use of barbed wire in the heart of Western civilization and, furthermore, in all three historically acknowledged dispositives: the enclosure of one's own, the enclosure of others, and the crosslinking of the space in-between. Wire has over time shown itself as a more resilient and efficient material than walls and ramparts due to its mobility (it is easy to install and remove) and, which is 
especially important, does not leave any traces after its removal, and this constitutes a particularly significant element of redesigning history and collective memory: "concentration camps are not built to last" (Razac 57) or "it was all music. ${ }^{\text {.1] }}$ The dynamism and the impermanence emphasize the time (and the metaphorical) aspect over the spatial aspect, while the repeatability of occurrence emphasizes certain archetypal meanings.

The paper analyzes the illustrated covers of the weekly newspaper Novosti, on which the motif of barbed and razor wire can be found, and which constitute a critical review of the migrant crisis (specifically targeting the European reaction to the crisis). As an established symbol of captivity and a metaphor of political violence, barbed wire carries predefined value-marked connotations, therefore, the dialectic implied by satire (cf. Simpson) is inevitably realized in the interaction of verbal and visual, with an especial emphasis on the procedure of saturation (as inflation in discourse); expressions and motifs, which are not connected denotationally, are frequently added, resulting in the formation of new meanings based on the multiple blending of mental spaces. The satirical and metaphoric potential of the motif of barbed wire is questioned through the interpretation of the selected covers, and the functions of the motif are determined through the deconstruction of the narrative of the longed for and civilized West.

\section{The Satirical and Metaphoric Potential of Barbed Wire}

Simpson (2003) considers satire a discursive practice and recognizes that satirical discourse designates the simultaneity of the aggression function (which implies a specific attack target and the superiority of the satirist), the social functions of cohesion within a group, and intellectual functions, based on introducing and interpreting verbal and visual signs that emphasize the absurdity of the presented. In the examples of satirical covers, the satirist often targets a specific social phenomenon, instead of a separate feature of a specific individual. When the targeted social phenomenon is a representative of power, the superiority of the satirist is fully in the segment of mediated knowledge (in contrast to power) ${ }^{[2]}$ that gathers a group that shares a common critical thought, but also activates a group of opponents to express various negative reactions ${ }^{[3]}$ Simpson presents also the basic functional relationship of the satirical discourse as a relationship of the components prime (as a context that is the central focus of attention) and dialectic (as an 
intratextual element that grows from the antithesis). Relying on Hegel's triad, it is Popper who presents dialectic logic as basic thought development, especially within the meaning of the continued genesis of opposition, simultaneously emphasizing how the antithesis is not formed by the thesis but the critical attitude, with the role of contradictions being especially productive (cf. Popper).

Wire as a negatively valued symbol of threat, limitation, and danger in satirical representations is placed into a contrasting visual and verbal context that suggests innocence, commodity, openness, and even leisure, where the discursive twist suggests the verbal (wordplay) or visual (pictorial representation), and often has an echoic function (as an echo of another discourse). The criticism of the wire on European Union borders is also a satirical representation of propagated European values. In the conceptualization of the abstract values metonymical and metaphorical mapping is used. Metonymy is (as mapping within the same domain, and especially when a part represents the whole) thus a typical pattern, while in the representations of open/closed space (as crossdomain mapping) it is metaphorization that comes into the foreground. The universal metaphorical mapping usually occurs by virtue of the conceptualization of abstract entities (subjective experience) through concrete entities (sensorimotor experience) (cf. Lakoff and Johnson 45), where barbed wire as a material object is a suitable sign in the source domain, ${ }^{[4]}$ while the target domain can represent abstract values, cognitive abilities, and emotions as well as the collective (social) body.

Unlike the stasis of regular wire used to enclose owned space or space with a special status, barbed wire emphasizes the dynamism of action and the intensification of division between the internal and the external; it creates delimitation with active surveillance and removal, and Razac thus names it a dispositive of the spatial application of power: "to protect the herd and kill the beast" (87), where the herd is a representative of economic value, and even social and state structures, while the body of the beast is susceptible to being wounded, as a bestial body of a nomad or the excluded.[ ${ }^{[5]}$ Barbed wire equates the human body with the animal body (graphically depicted in the examples of photographs from Nazi concentration camps and Soviet gulags, cf. Netz), while the dehumanization in the deeper layers of connotations also involves the background of images (in the meaning of a critical view of the mechanism of managing the barbed wire, which 
is almost equally a mechanism of power and a mechanism of passive observers). Within the narrative of the migrant crisis, the historical scene of the invention of the economic exploitation of barbed wire is repeated: enclosing the space of land cultivated by farmers and preventing unobstructed passage of cattle, cattle herders, and other nomads through such a segmented territory (cf. Razac); a blended concept of bestiality of the enclosed off cattle is already bidirectional in this source narrative and dependent on the perspective (eye) of the observer.

Linear segmentation characterizes the transformation of the world into a city-polis as a "homogenous and isotopic political space" (Deleuze and Guattari 235) that sporadically generates a molecular segmentation which the same authors connect to micro fascisms.

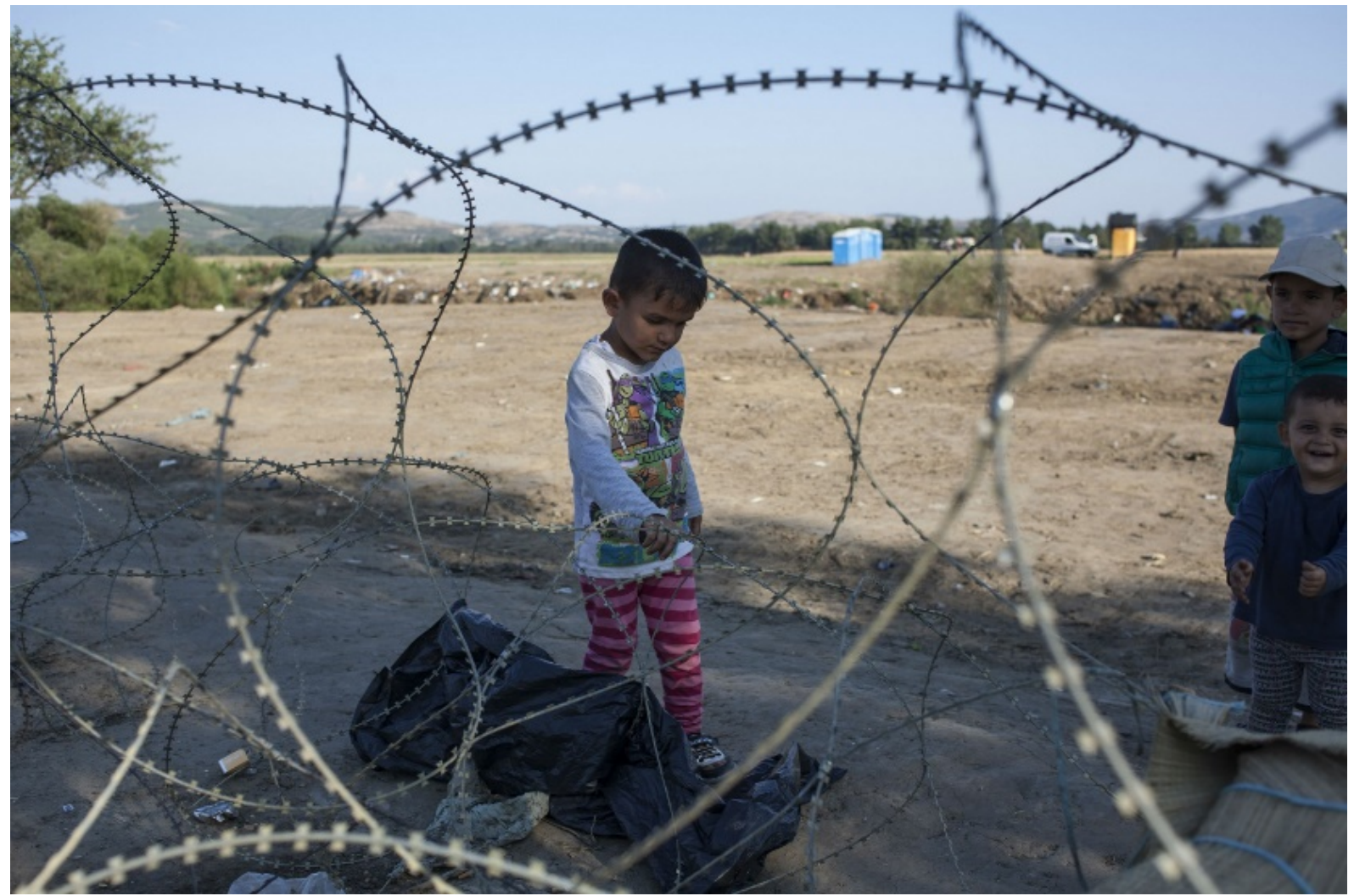

Image 1. The Greek-Macedonian border (Grosso).

The strained relationship between multiple segmentation and the open, undefined space of nomads is an archetypal relationship of the striated sedentary space and the smooth space of the desert, the state, and the war machine, while the barbed wire as a material and dynamic means of striation is at the same time a representation of segmentation and a line of fictional escape ${ }^{[6]}$ 
The barbed wire is reinterpreted in art installations ${ }^{[7]}$ with an emphasis, among others, on the opposition of the real and imagined space. Marina Đira in her sculpture installations represents with barbed wire a Shore of a generic city - the edge of the world and the physical, and a frontier towards the unobtainable open space of longing (cf. Đira).

The Israeli artist Sigalit Landau brings to the fore, with her performance Barbed Hula (2000), the female body and the wounding, however, the liminality created in this example shows as inseparable the symbolic characteristic of barbed wire: a body in a wire hoop is contrasted with a beach as a natural territorial border.

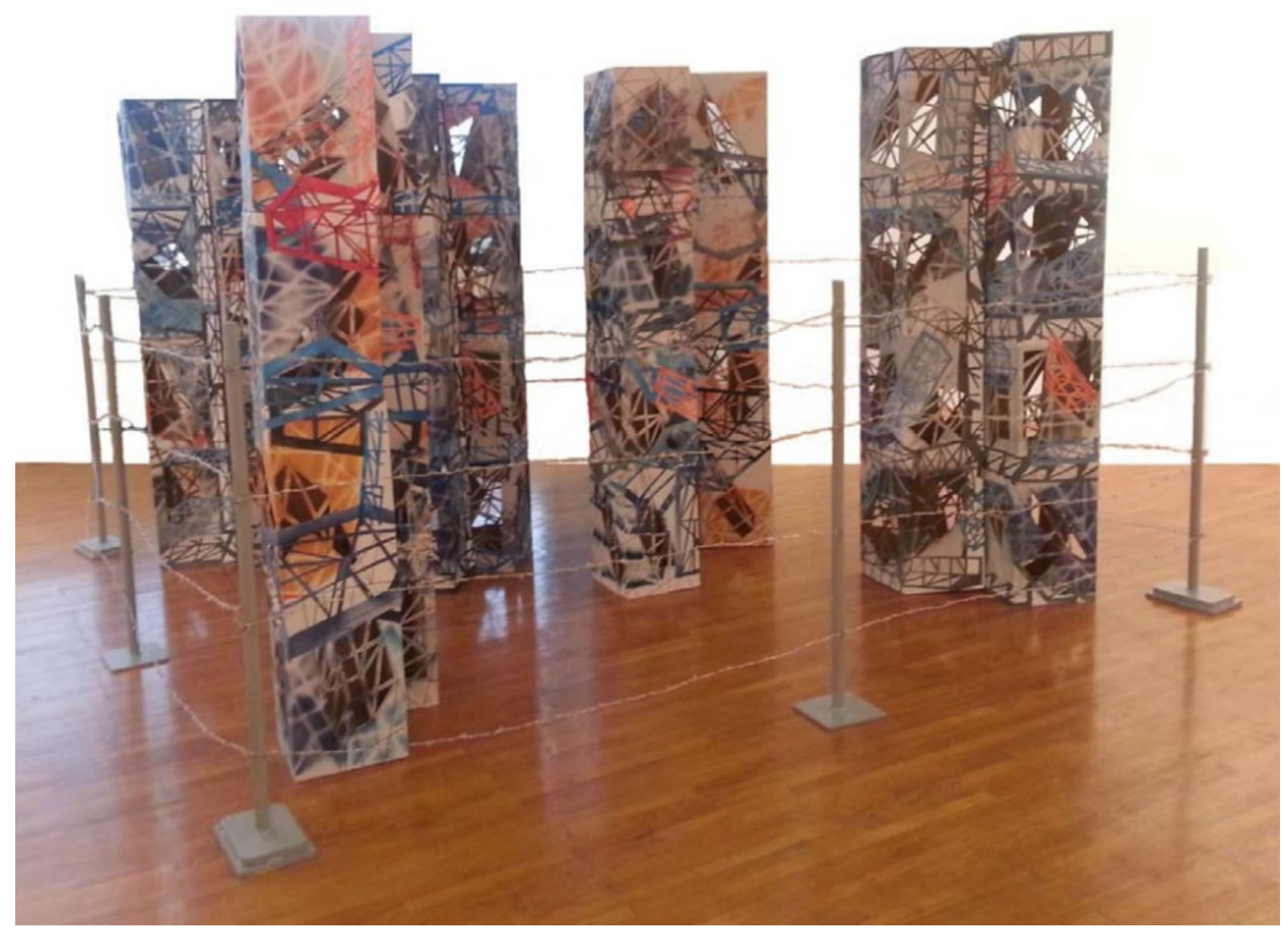

Image 2. Marina Đira: Barbed wire in visual art: the symbol of longing for open space, sculpture installation, cca. $300 \times 300 \times 200 \mathrm{~cm}, 2014$ (Đira 86).

[8] 
These examples present the motif of longing and the visual metaphor that in its source domain includes the encircled/captive city/body where the perspective of the internal and the external is inverted: the outside observer becomes the involved participant of the presented emotion.

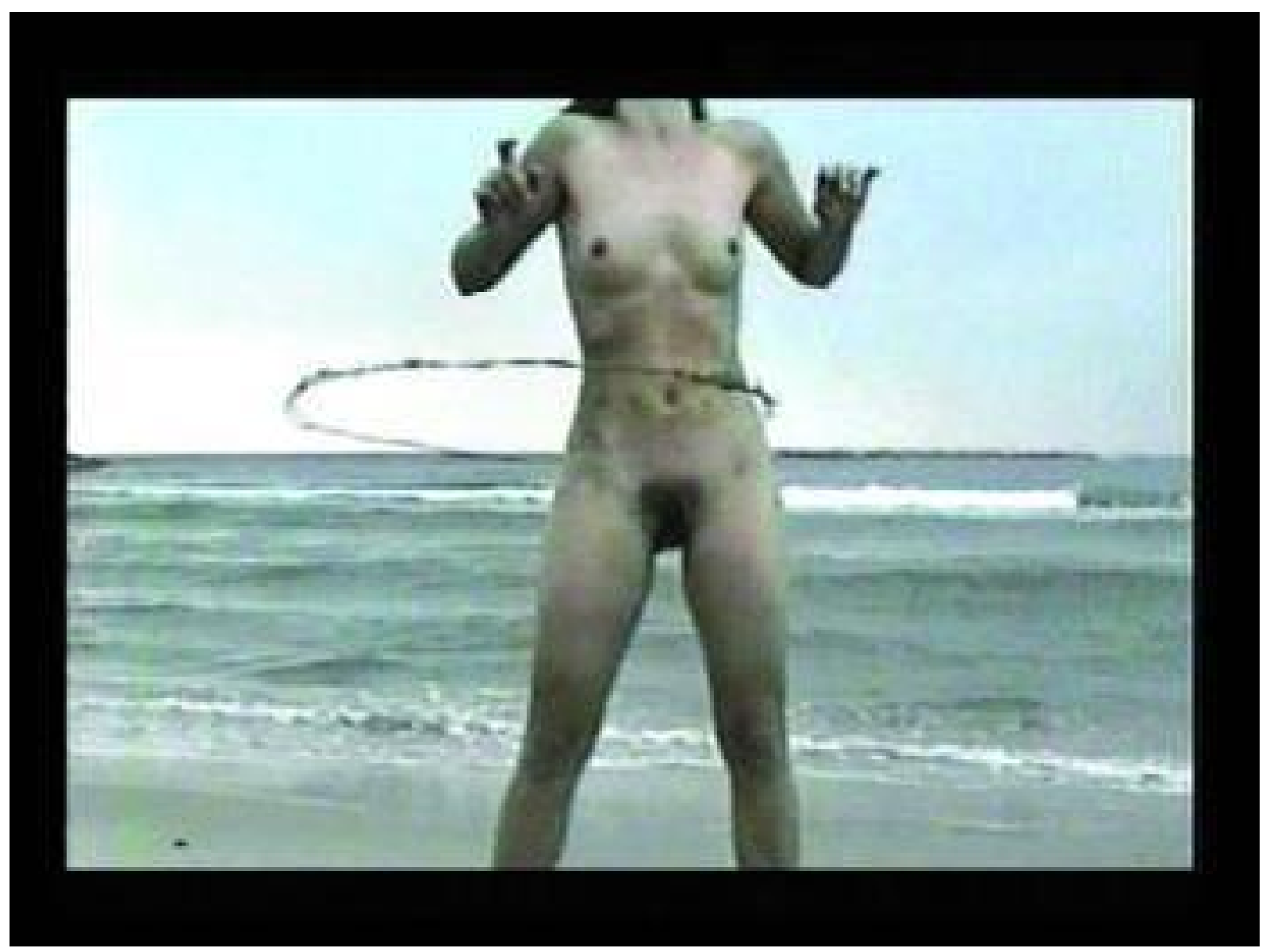

Image 3. Sigalit Landau, Barbed Hula, 2001, excerpt ("Barbed Hula”).

It has already been recognized that the similarity is established through visual metaphor as physical resemblance, and subsequently as simultaneous cueing but also as filling a schematic slot unexpectedly (cf. Forceville). The established unexpected context as the resultant combination of diverse visual or verbo-visual signs is the fundamental element of the satirical dialectic, and due to conceptual grounding also a productive field of metaphorical meaning.

\section{Examples of Barbed Wire in Illustrations on Satirical Covers}

The created surveillance and danger, the closing of space, and the strict segmentation in the artistic and critical interpretations of barbed wire on the covers of the political weekly newspaper 
Novosti ${ }^{[9]}$ even though detached from realistic representation by technique (a drawing illustration),

[10] through evoked experiences, knowledge of the material world, and layering of intratextual meanings represent an echo of reality, and can be grouped around two essential semantic characteristics (also the effects of the depicted object) - acting on the body (wounding) and enclosing space (excluding). Placing the wire in contrasting contexts of commodity and, especially, of wordplay downgrades to a certain extent the seriousness of its primary symbolic meaning, so as to dialectically combine, in a critical conclusion, the elements in a new blended meaning that equally targets a social phenomenon that is the subject of satire and the observer of the satire (in the sense that there are no innocents).

\subsection{Acting on the Body}

Wounding as an immediate action on the body of the excluded, created by barbed wire, has an archetypal image in the motif of a thorn crown that designates the earthly body of Christ the Sufferer. With a satirical inversion, the motif of the martyr wounding of the righteous is placed into the commodity of leisure (presented through sports and other aspects of popular culture).

On the cover "Ave Cerar," which references the enclosing of the Slovenian-Croatian border with barbed wire on the Slovenian side, the barbed wire is moulded in the form of a pommel horse (the gymnastics apparatus on which the father of the then Slovenian prime minister, the Olympic winner Miroslav Cerar, one of the most famous Yugoslav athletes, made his name). 

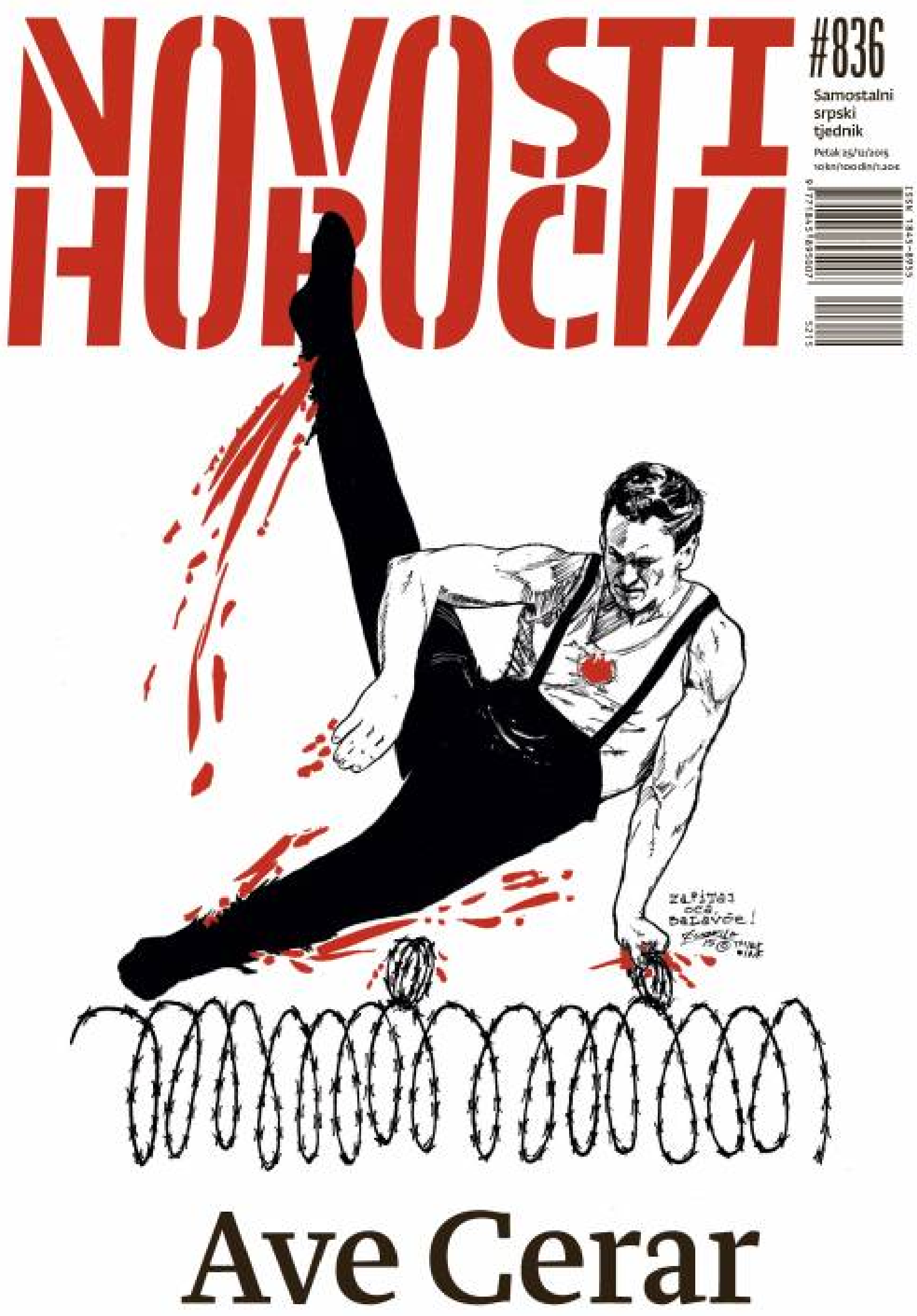

Image 4. Alem Ćurin, the cover of Novosti 836 ("Galerija naslovnica"). 
The role of the Slovenian prime minister is presented dialectically: the position of power (evoked by a Roman salute) is contrasted to his personal origins that were, besides visually, patronizingly explicated with a verbal message: Ask your father, brat (Zapitaj oca balavče). Personal heritage is shown in that example as a general human susceptibility to wounds. The barbed wire is on the other side, as an object that causes wounds, set up as a contrast to the idea of olympism (in the principles of equality that it advocates for, thus, as an aspect of the emphasis on the general interconnectedness of humanity), and in the special layer of meaning also evoking the uniqueness of the imaginary territory within which it is set up.

In the example described by the background text as Border contemplation (Granična kontemplacija), which also evokes a motif from the edge of intellect, the satiation with various verbal and vital signs (accompanied at a mental level by multiple input space ${ }^{[11]}$ ) activates several interpretive layers. 

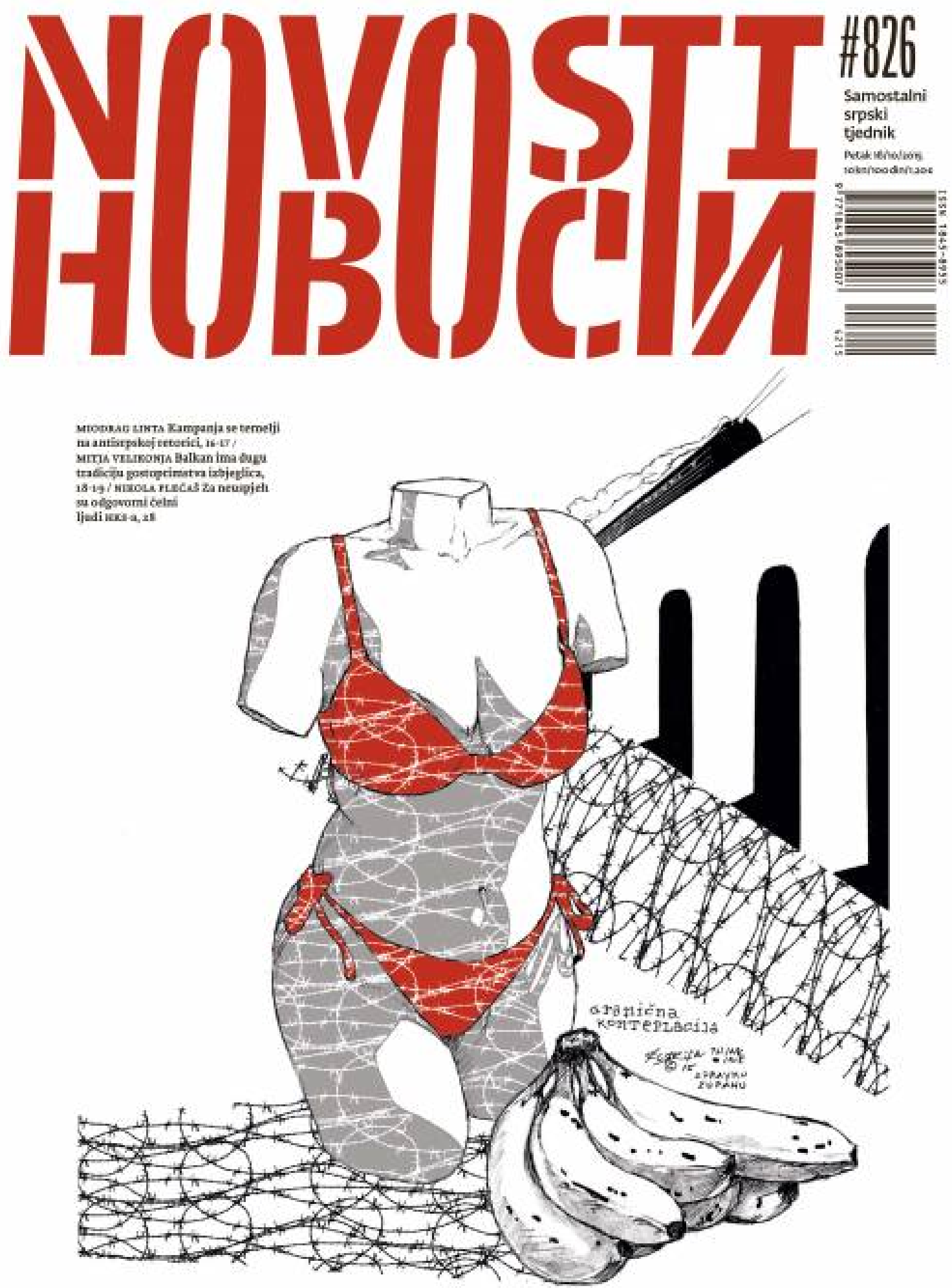

\section{Lutka sa naslovne grane $_{m, 3}$}

Image 5. Alem Ćurin, the cover of Novosti 826 ("Galerija naslovnica"). 
In the center is a female torso in a red Baywatch swimming suit ${ }^{12]}$ intertwined with a shadow of barbed wire, evoking the comic title of a headhunter. The barbed wire is placed in the space before and behind the torso, so that the space is also satiated with wire on a denotative level. The verbal title evokes the phraseme "a cover doll" ("lutka s naslovne strane"), the term originally used for the stereotypical description of photo models. "Lutka sa naslovne strane" is a famous song by the Yugoslav band Riblja čorba ${ }^{[13]}$ whose author later became an advocate for nationalist and, sporadically, chauvinist ideas. On the one hand, bananas with the highlighted text suggest a pejorative relationship of racial discrimination towards migrants by the representatives of power that erect barbed wire, expressly supported by nationalist politics, and, on the other hand, a pejorative relationship of satirists' gender discrimination towards the intellect of a female president who had expressed a negative attitude towards the politics of open doors and a certain sympathy towards neighbouring countries that had enclosed themselves with wire.

The minimalist cover with a child's head and razor wire, one ring of which covers the eyes, and the other threateningly descends towards the neck (as a place where the mortal wound was given), is accompanied by the following text: when butterflies wish for caterpillars (kada se leptiri užele gusjenica), that evokes the disorder in the development stage of the species but also contrasts the innocence of a beardless child and the cruelty of metal razor. 

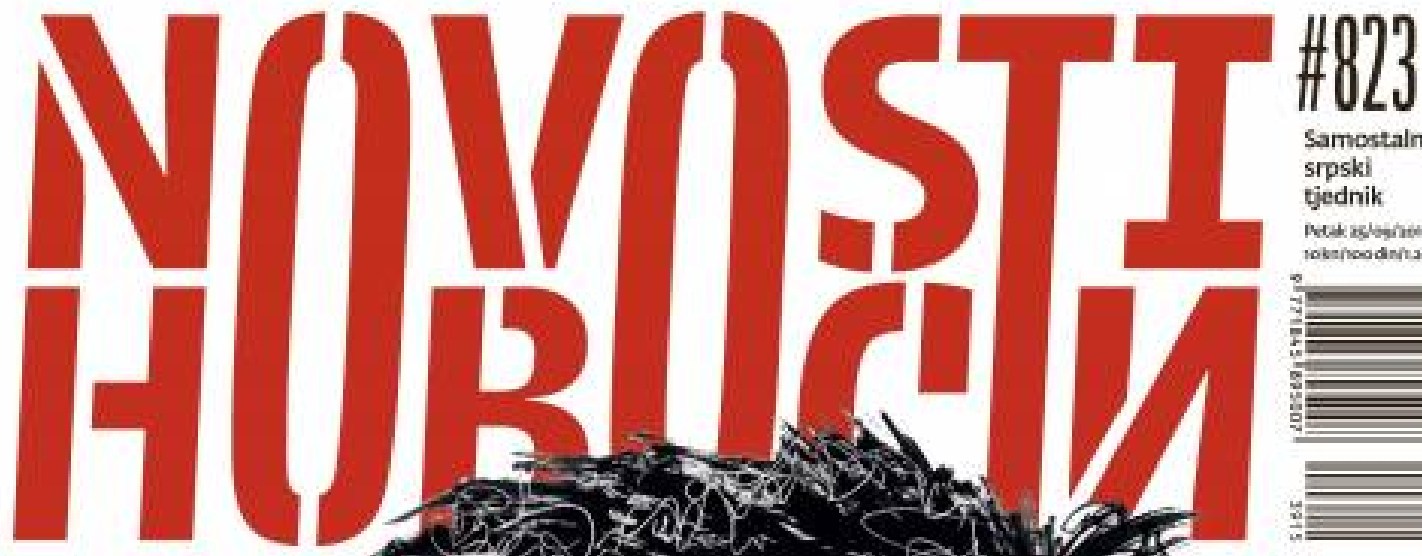

Samostalni srpski tjednik

pecas asloghes roknhoodnituec
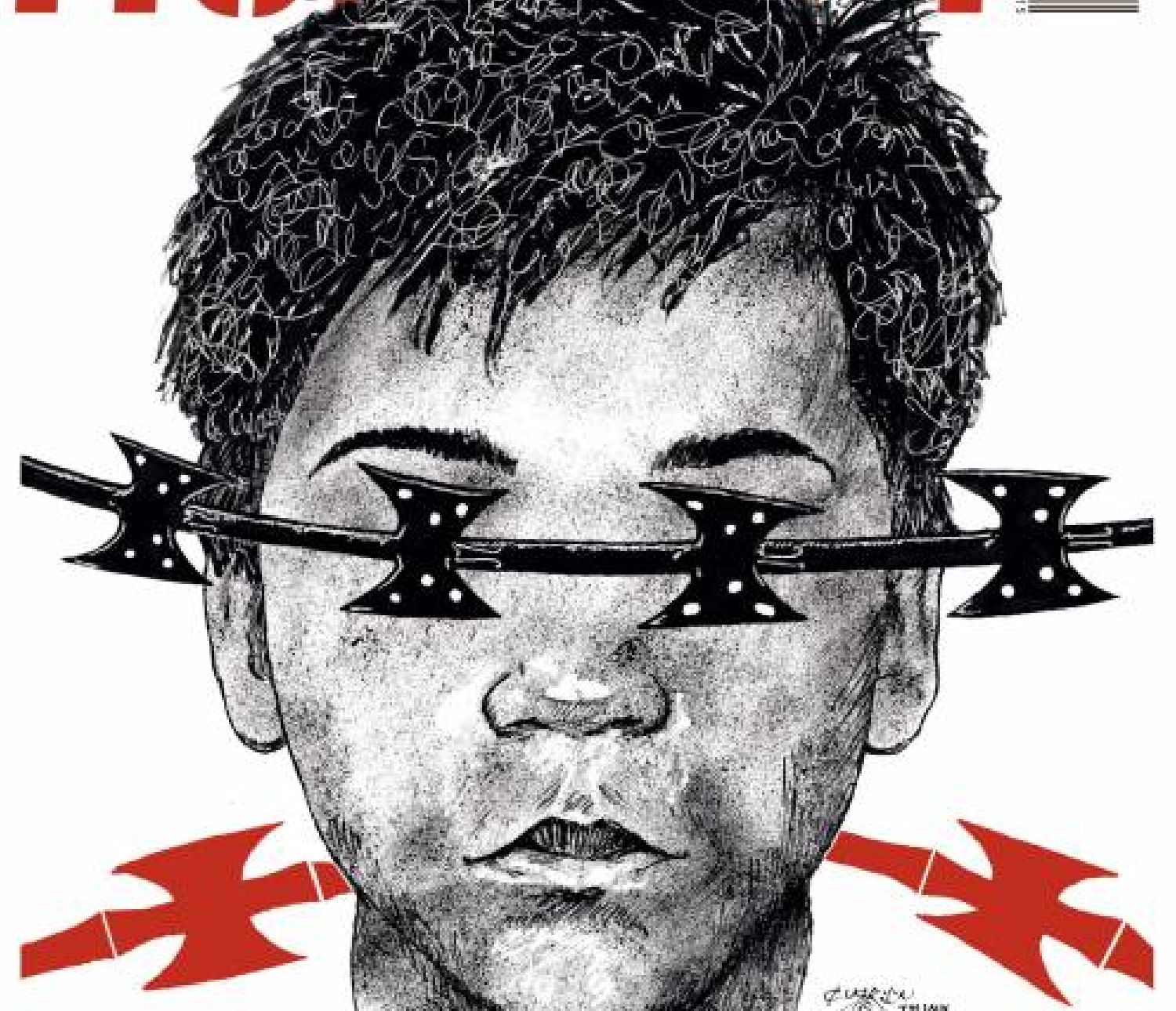

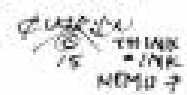
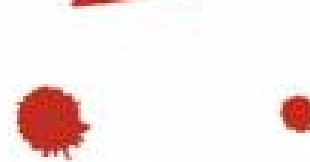

KaD se IepTiri

užele Gusjenica

Image 6. Alem Ćurin, the cover of Novosti 823 ("Galerija naslovnica"). 
Besides the ambiguous verbal text, the author did not use a more explicit visual representation but stopped at the razor wire as a universal symbol of danger and foreboding and at the covered eyes as a blended visual sign: covered eyes do not watch and thus do not know ${ }^{[14]}$ nor disturb the observer. In contrast (as a manifestation of disturbing knowledge), in the famous art photo by Nathan Lerner Eye and Barbed Wire from 1939, the wide-open eye watches from the ground (which can represent also a burial ground) that is criss-crossed with barbed wire (Krell 8).

That the issue of insensitivity to the death of children is as a subject of satire depicted with a more explicit visual dialectic can be seen in the famous example of the cover of the journal Charlie Hebdo, on which the real picture of a drowned migrant child with its face turned towards the ground was turned into a drawing with an advertising poster for McDonald's with a face of a clown who advertises two kid menus for the price of one (cf.

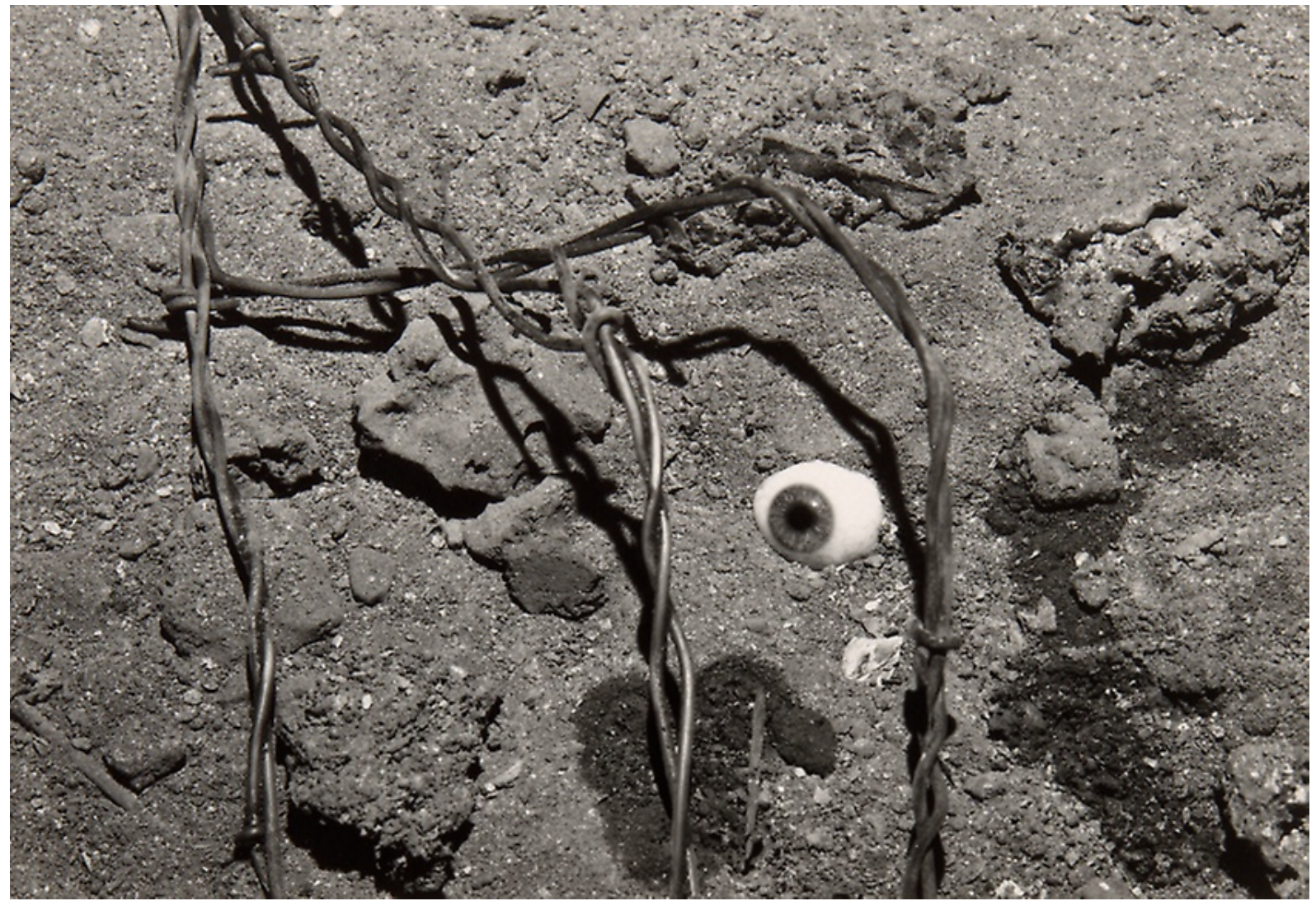

Image 6a. Eye and Barbed Wire. Nathan Lerner. 1939.

MS). 
The cover, presented in a minimalist manner but with visual and verbal signs that in the multiple input spaces of knowledge and experiences generate blended concepts, deals with the action of razor wire on the dehumanized body: a razor, hollowed in the middle in the form of barbed wire and on which mooching for razors (žicanje žileta) is written, bisects almost monstrous feet, with toes peeking out (evoking also the phraseme "a slap on the wrist," as the phrase in Croatian is "getting a slap on the fingers" / dobiti po prstima). 

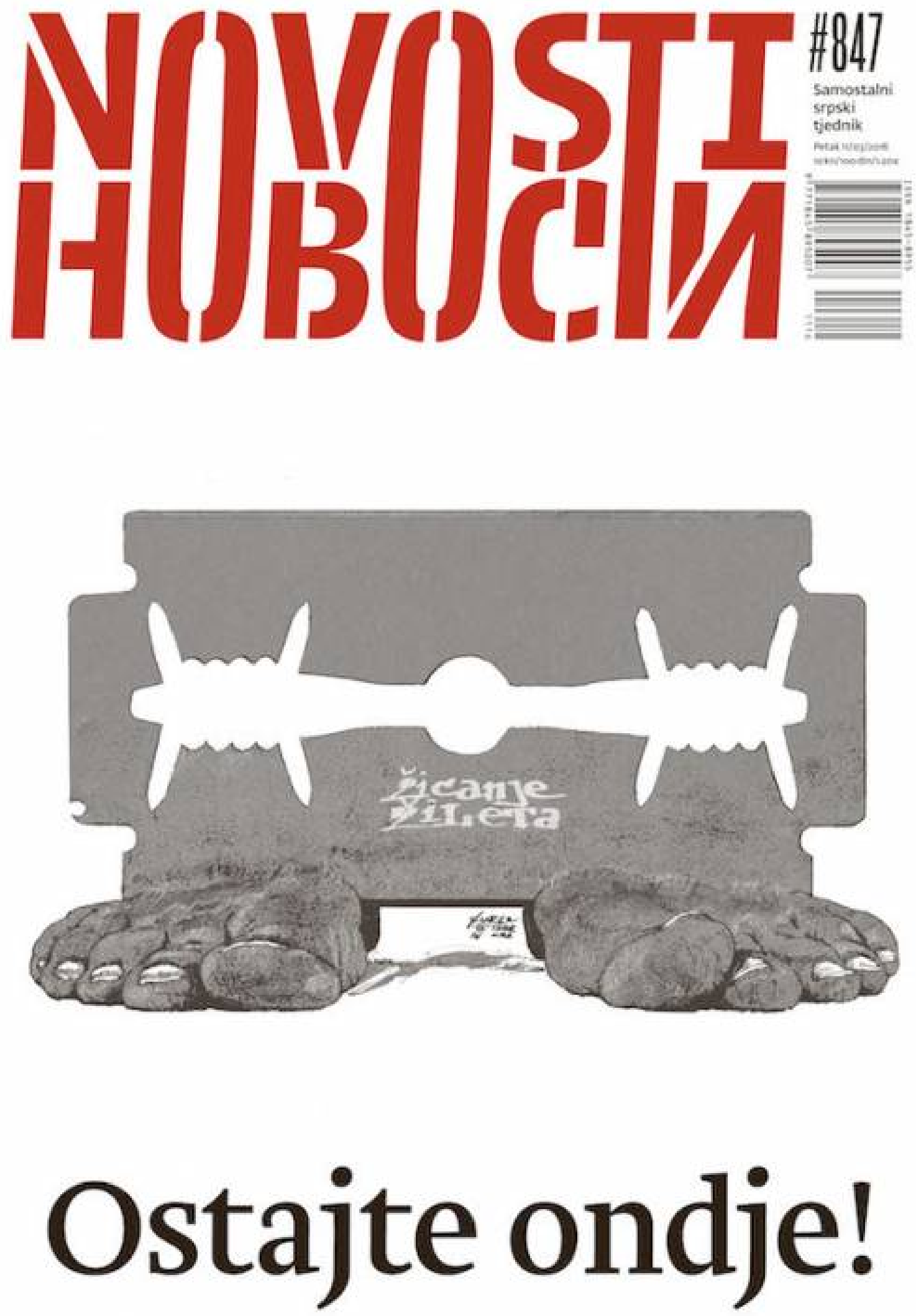

Image 7. Alem Ćurin, the cover of Novosti 847 ("Galerija naslovnica"). 
The image has a commanding title: Stay there! (Ostajte ondje!), a contrasting version in its identity and also spatially of the canonical song by Aleksa Šantić, the Bosnian-Herzegovinian and Serbian poet from Mostar: "Stay here..." is originally addressed to the reverse migrant wave that had occurred in the past, to the Bosnian Muslims who had under the Austrian-Hungarian rule migrated to Turkey ${ }^{[15]}$ The multiethnic and multidenominational context of holy blood from Šantić's poem is actually the context of the superior holy ground. The criticism of enclosing space points out that the narrative of staying here applies only to the community of natives, the community of us who belong, and not to the eradicated nomadic others. By evoking Šantić's song, the song of nativism is relativized: stay there where you have migrated to in the past, and thus downgrades the seriousness and relativizes the ideologeme of holy ground. The razor that cuts the feet symbolizes a dynamic and current border of geographical space, which is also an unstable social boundary between us and the others.

\subsection{Enclosing space}

Marking the border with barbed wire encompasses the representation of a static symbol of danger and space under surveillance as well as a contextual metaphor of longing for imaginary open space and a metaphor based on dynamism.

In the example titled Second Yugoslavia? (Drugoslavija?), which visually thematizes the exit of Great Britain from the EU, and verbally evokes the earlier breakup of a multiethnic state community as a question mark over the future of the united countries of the British kingdom, the geographical representations of territories are personified by the highlighted parts of body and movement. 

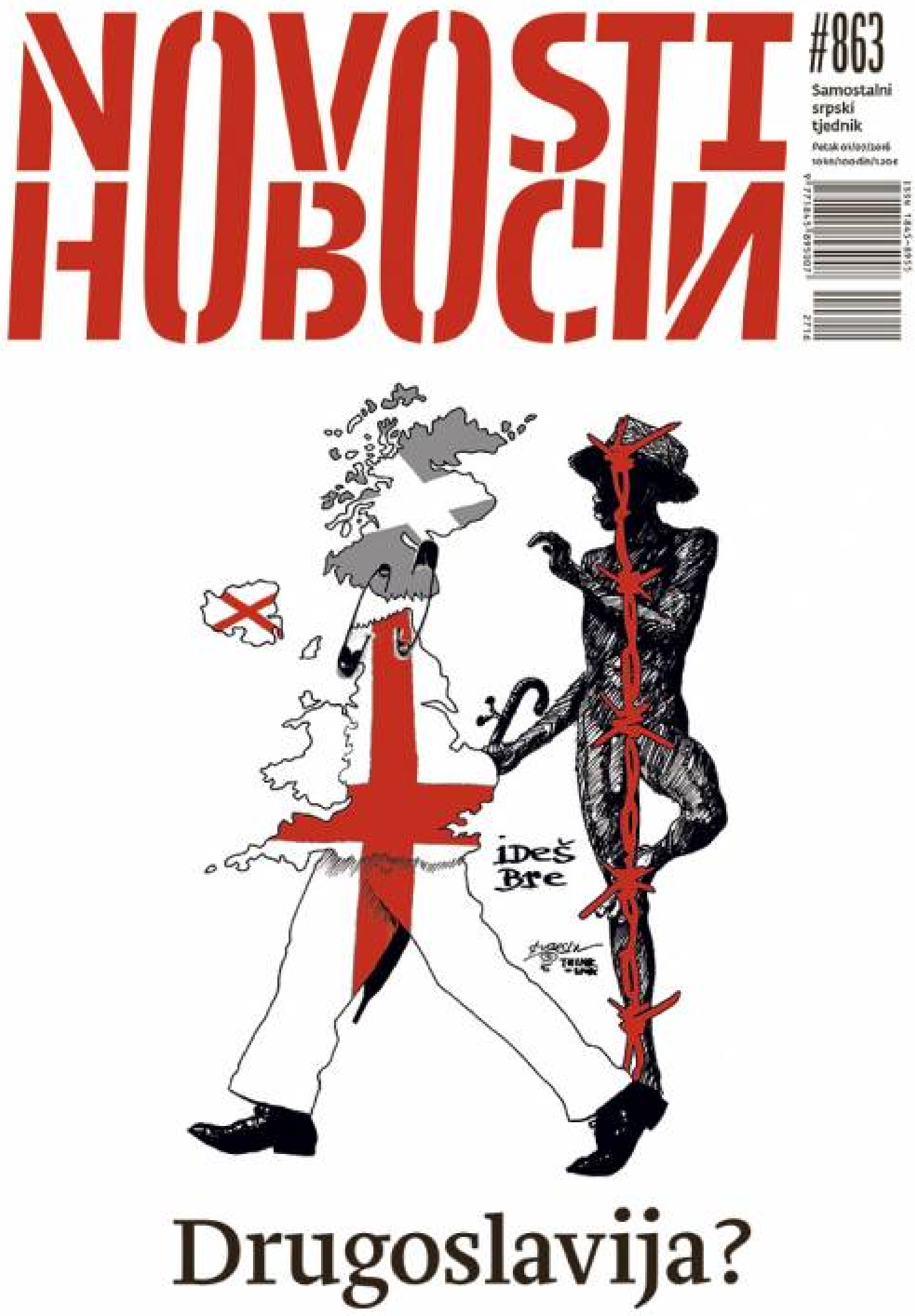

Image 8. Alem Ćurin, the cover of Novosti 863 ("Galerija naslovnica"). 
The representation of UK especially emphasizes the legs while the head is unformed (in the sense of a human form) and loosely connected, which critically inverts the hierarchy of a body-politic metaphor ${ }^{[16]}$ A red barbed wire is place on the personified body of a jovial European continent, as a dominant symbol. The barbed wire in the example is not thematized as a material acting on the body but is an abstract symbol of wire that also becomes an emblem (a backbone) of the community of European countries and is simultaneously a segment of the dehumanization of a personified representation (and metonymically of the community it represents).

The example Bulwark of the Schengen Area (Predziđe šengenstva) expounds on and downgrades the seriousness of the historical narrative (from the time of Turkish conquests in the 16th century) of Croatia as the bulwark of Christianity, which is through wordplay oversaturated by the current efforts to access the Schengen border regime that ensures open borders between countries it encompasses as well as a closed outer border, which is in actuality connected with financial investments and the guaranteed proclamative stability (explicated with the text in the background: antemorale christianitatis you know its last name [Gotovina 'cash'] (antemorale christianitatis prezime mu znate). 

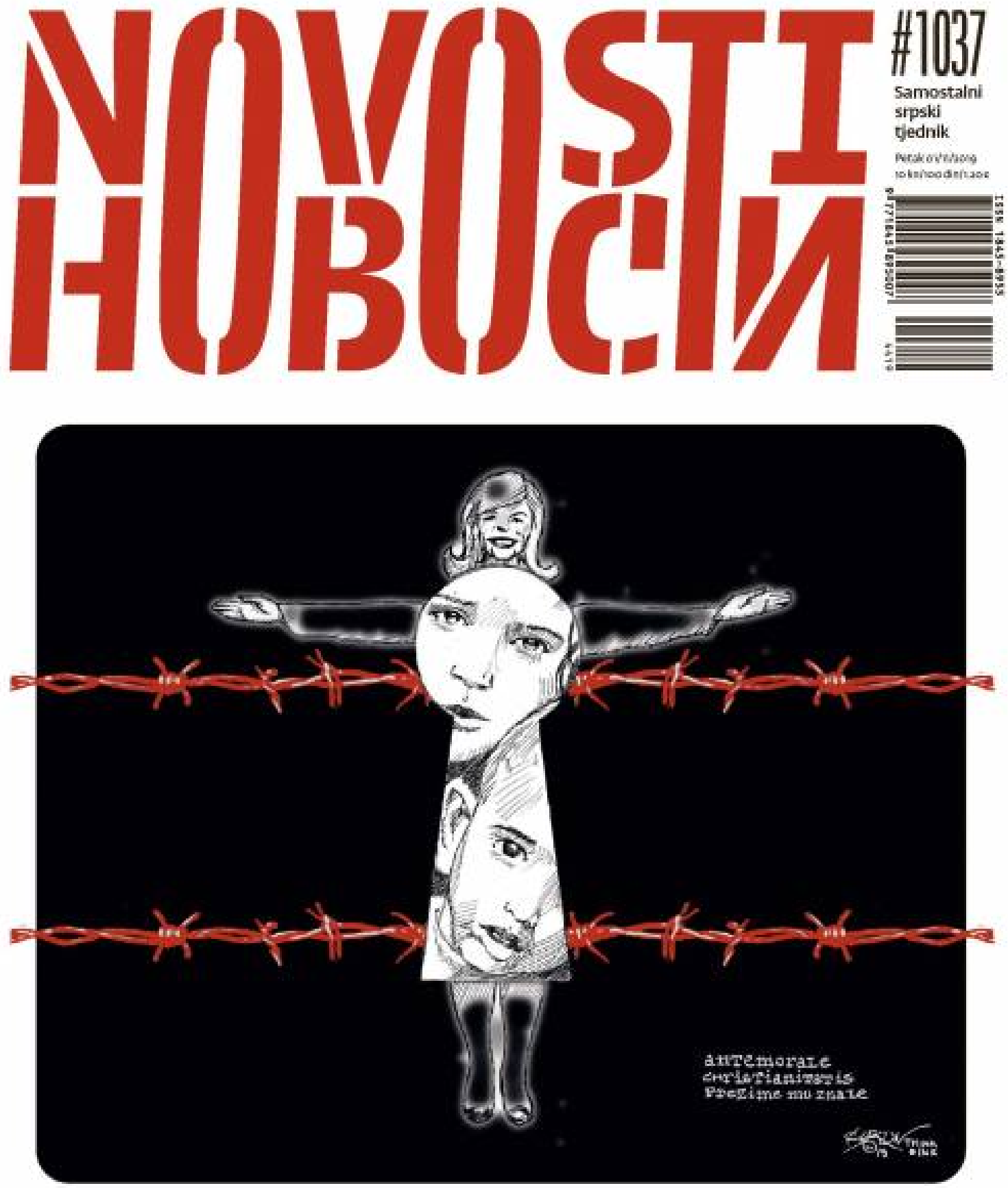

\section{Predziđe šengenstva}

Bruxelles je zalupio vrata Sjevernoj Makedoniji, Albaniji i ostalima, što ce pogoršati odnose na Balkanu, a Hrvatskoj je istovremeno namijenio ulogu evropske vojne krajine koja čuva šengenske granice $=$ z 
The country is metaphorically presented as a person (the female body in the example is not an object of exploitation but a symbol of a happy guardian) positioned, as a traffic control to stop movement, into an analogue relationship with the metal boundary of a red barbed wire. The bodypolitic metaphor is here, as an archetype of Mother Earth, emphasized with hands (protection and safety) and again dehumanized by an analogy with the spreading of barbed wire. The inversion of the perception of the open and closed space, on which the satiric inversion is based, is contingent on the visual metaphor of a container and the gaze. The woman's torso is a locked container: children are looking through an opening/a keyhole of their enclosed inner space into the desired space of freedom and prosperity that is enclosed with barbed wire and is also the space of the observer of the satire. This makes the metaphorical gaze bidirectional and introspective.

The barbed wire is the central motif of a metaphoric representation of the Mediterranean as a tomb of African migrants (with the central motif of children drowning). 


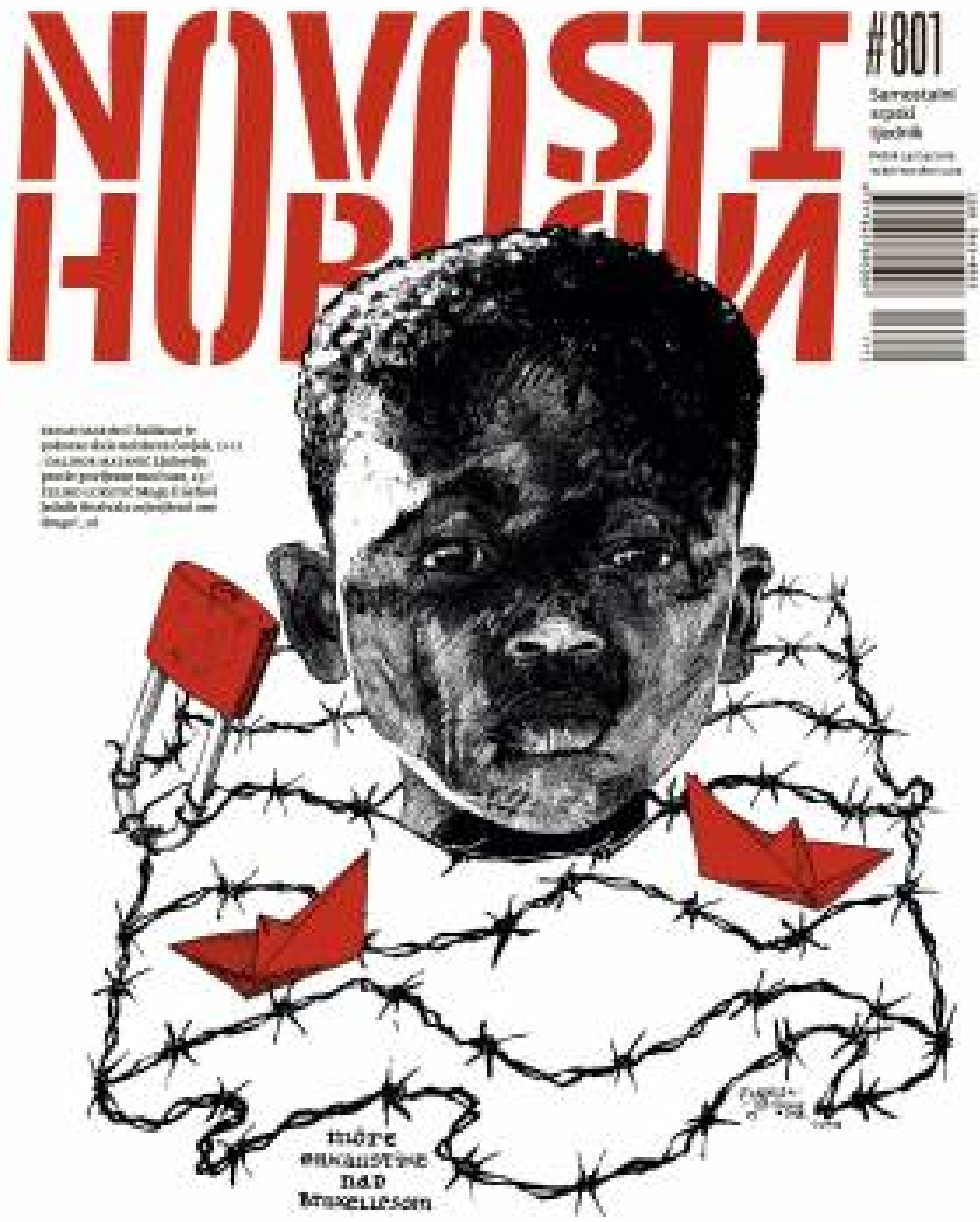

\section{Humanitrajna katastrofa}

Moditeran fe postao permancatma grobnica ikgalnih migranat, Eenu dopri-

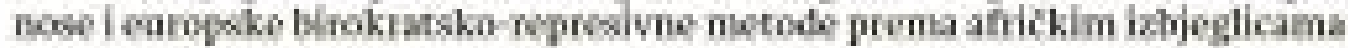
thitit 
The metaphor here is also grounded in the inversion of the relationship between the outside and the inside, the relationship between the closed and the open space. The sea expanse, which is an open smooth space on a fictional level, is closed and segmented with a barbed wire that produces metal waves ${ }^{[17]}$ Instead of being a symbol of danger in a certain space, the barbed wire is thus transformed into the very space itself - the Mediterranean as a historic melting pot of cultures and the cradle of Western civilization is explicated as a monitored space of no man's land, a manufactured trap for implementing selection and exclusivity. In Deleuze's terminology, the principles of blending and of the heterogeneity of the rhizome of sea storms are replaced by a layered intertwining: spots/points/traps are set to which the routes of the new kind of "archetypal nomads" (Deleuze and Guattari 544) are subjected. The wordplay in the title: Humaniconstant catastrophe (Humanitrajna katastofa) ${ }^{[18]}$ emphasizes the time aspect (permanence as hopelessness). By deconstructing lexemes, the notion of humanitarianism is deconstructed as an ideologeme of the proclaimed and at the same time unachievable action. The text in the background: a sea of hurricanes over Bruxelles (more orkanštine nad Bruxellesom), calls out the source of bureaucratic repression and the center of power as the origin of the contemporary ideologeme of the European ground that must be defended. The Sea of Silence is mirroring this in imagination, on the light side of the Moon, astronomically defined and measured.

\section{Conclusion}

The above-mentioned examples of barbed wire in the context of the current migrant crisis confirm that barbed wire is an established symbol, the basic semantic features of which cannot be changed; therefore, the satiric potential of barbed wire is achievable through the dialectic that grows from the context into which it was introduced, the context which is typically created for barbed wire by antithetic designations of the various manifestations of commodity, where the stratification of meanings is pronounced. The abundance of verbal and visual signs on covers is not proportional to the multitude of implied meanings: minimalist covers have as many interpretative layers as do covers saturated with diverse signs. It is in the potential of establishing an antithesis that lies the pronounced artistic and critical functionality of the motif of barbed wire. Artificial production and natural environment, open and closed space, human and dehumanized 
are contrasted. Artificial production is marked by a bureaucratic apparatus positioned as a new form of totalitarianism. The representation of humanity is not in the segment of power but in the characteristic of wounding, the dynamic of unobstructed movement, and the gaze. In the inversion of the perception of closed and open space, barbed wire is represented also by a productive motif of a metaphoric image where the gaze of the oppressed from the closed space is blended with the observer's gaze that also contains various segments of mediated knowledge. The segment of subversive action is mostly kept at the level of introspection in the studied examples, instead of transferring the focus on the production of controversies and the provocation of social reaction, with the critical discourse meeting the empathy of satirists and the recipients of satire.

\section{Work Cited}

Deleuze, Gilles and Félix Guattari. Kapitalizam i shizofrenija 2: Tisuću platoa [Capitalism and Schizophrenia]. Translated by Marko Gregorić, Sandorf, 2013.

Dixon, Wheeler Winston, and Richard Graham. A Brief History of Comic Book Movies. Palgrave Macmillan, 2017.

Đira, Marina. Bodljikava žica u vizualnim umjetnostima: simbol čežnje za otvorenim prostranstvom. 2014. Akademija likovnih umjetnosti u Zagrebu, doktorska disertacija.

Fauconnier, Gilles, and Mark Turner. "Conceptual Integration Networks." Cognitive Science, vol. 22, no 2., 1998, pp. 133-87.

Forceville, Charles. "Non-verbal and Multimodal Metaphor in a Cognitivist Framework: Agendas for Research." Cognitive Linguistics: Current Applications and Future Perspectives, edited by Gitte Kristiansen, Michel Achard, René Dirven and Francisco Ruiz de Mendoza Ibàñez, Mouton de Gruyter, 2006, pp. 379-402.

Foucault, Michael. Nadzor i kazna: rađanje zatvora [Discipline and Punish: The Birth of the Prison]. Translated by Divina Marion, Informator, 1994.

Foucault, Michael. Znanje i moć [Power/Knowledge]. Translated by Rade Kalanj, Nakladni zavod Globus, 1994. 
Foucault, Michel. "O drugim prostorima ["Of Other Spaces”]." Operacija: Grad. Priručnik za život u neoliberalnoj stvarnosti, edited by Leonardo Kovačević et al., Multimedijalni institut, 2008, pp. 31-39.

“Galerija naslovnica." Portal Novosti, www.portalnovosti.com/galerija. Accessed 30 Aug. 2020. Grosso, Eugenio. "In pictures: The Barbed Wire Fences that Scar Refugees and Europe." Middle East Eye, 13 Apr. 2019, www.middleeasteye.net/gallery/pictures-barbed-wire-fences-borderseurope-keeps-out-refugees. Accessed 15 Sept. 2020.

Ivančić, Viktor. "Humanitrajna katastrofa." Feral Tribune, 17 May 1999, www.v6.infobiro.ba/article/606883. Accessed 15 Sept. 2020.

Krell, Alan. The Devil's Rope. A Cultural History of Barbed Wire. Reaktion Books, 2002.

Lakoff, George, and Mark Johnson. Philosophy in the Flesh: The Embodied Mind and Its Challenge to Western Thought. Basic Books, 1999.

Landau, Sigalit. Barbed Hula. Sigalit Landau, 2000, www.sigalitlandau.com/barbedhula. Accessed 12 Sept. 2020.

Landau Sigalit. "Barbed Hula." Re.Act Feminism: A Performing Archive, 2001, www.reactfeminism.org/entry.php?|=lb\&id=95\&e=a. Accessed 25 Sept. 2020.

Lerner, Nathan. Eye and Barbed Wire. 1939, Art Institute Chicago, www.artic.edu/artworks/213387/eye-and-barbed-wire. Accessed 15 Sept. 2020.

MS, Adam. "Controversial New Charlie Hebdo Migrant Cartoons Draw Criticism." Adam's Corner, 15 Sept. 2015, theadamscorner.wordpress.com/2015/09/15/controversial-new-charlie-hebdomigrant-cartoons-draw-criticism/. Accessed 15 Sept. 2020.

Musolff, Andreas. "The Metaphor of the 'Body Politic' Across Languages and Cultures." Cognitive Explorations into Metaphor and Metonymy, edited by Frank Polzenhagen, Zoltán Kövecses, Stefanie Vogelbacher, and Sonja Kleinke, Peter Lang, 2014, pp. 85-99.

Netz, Reviel. Barbed Wire: An Ecology of Modernity. Wesleyan University Press. 2004.

Pavelić, Boris. Smijeh slobode: Uvod u Feral Tribune. Adamić, 2015. 
Popper, Karl R. “What is Dialectic?” Mind, vol. XLIX, no. 194, Apr. 1940, pp. 403-26.

Razac, Olivier. Politička povijest bodljikave žice: Prerija, rov, logor [Barbed Wire: A Political History]. Translated by Leonardo Kovačević. Naklada Ljevak, 2009.

Simpson, Paul. On the Discourse of Satire: Towards a Stylistic Model of Satirical Humor. John Benjamins Publishing Company, 2003.

Stanojević, Mateusz-Milan. Konceptualna metafora: temeljni pojmovi, teorijski pristupi i metode [ Conceptual Metaphor: Basic Concepts, Theoretical Approaches and Methods]. Srednja Europa, 2013.

Šantić, Aleksa. Pesme [Poems]. Edited by Jovan Radulović, Nolit, 1956. 
[1] "It Was All Music" ("Sve je bila muzika") is the title of an article in Feral Tribune (1998), which critically reviews the relativisation of crimes committed in a fascist concentration camp during the Second World War, accompanied by a photomontage of a fleeing camp commandant with a guitar whose strings have been replaced by barbed wire (cf. Pavelić 422).

[2] On the dialectic of knowledge and power, cf. Foucault, Nadzor.

[3] Satire, in general, aims to strengthen the connection between the satirist and the satiree/addressee by increasing the gap between the satiree and the satirized/target; however, this also achieves a sort of an opposite effect by connecting specific groups of recipients with the target of satire (cf. Simpson).

[4] The durability of a sign underscores the conceptual status of the source domain: "In a visually literate society, a vast number of endlessly repeated and recycled images (such as famous paintings, photographs, film shots, flags, logos, animation characters) evoke specific phenomena and events in a clichéd, shorthand manner widely shared within a community, and hence arguably aspire to conceptual status" (Forceville 389).

[5] The enclosed space is by its function of surveillance and exclusion a typical form of other space (Foucault, "O drugim"; Foucault, Znanje), while barbed wire explicates and lays bare the methods of separation that are in other forms represented more subtly. The visibility of huge ramparts, for example, does not have to be proportional to the visibility (transparency) of exclusion methods practiced within them.

[6] The dialectic of smooth and striated space as the translation and transformation of smooth space into striated space, and the reversal and the return of the striated into smooth space is emphasized by Deleuze and Guattari (540).

[7] On the representation of barbed wire in art, media, and popular culture cf. Krell 2002.

[8] The artist states in the description of the performance: "This act of desensitization - spinning a hula hoop of barbed wire - I performed at sunrise on a southern beach of Tel-Aviv, where fishermen and old people come to start their day and exercise. The beach is the only calm and natural border Israel has. Danger is generated from history into life and into the body. In this video 
loop I am performing a hula belly dance. This is a personal and senso-political act concerned with invisible, sub-skin borders, surrounding the body actively and endlessly. All my work relates, in one way or another, to a loss of orientation. The pain here is escaped by the speed of the act, and the fact that the spikes of the barbed wire are mostly turned outwards" (Landau, Barbed Hula).

[9] Novosti as a weekly newspaper of the Serb National Council, the umbrella cultural organisation of the Serb national minority in the Republic of Croatia, manages to maintain (relying on the strategy of positive discrimination) a sort of a satirical feuilleton (emphasized with satirical covers which are graphic illustrations of the graphic artist Alem Ćurin). The precursors of the satire presented in Novosti (the Sunday supplement of Slobodna Dalmacija since the 1980s, and later Feral Tribune in the 1990s and the first decade of the 21 st century) have been shut down due to economic unsustainability of publishing satirical content, which is generated mostly by sociopolitical intolerance (more can be found on this in Pavelić). It is not irrelevant to mention that the publishers of Novosti are also political actors of the governing majority, and that this is an example of the continued existence of controlled satire as a manifestation of power.

[10] The satirical covers of the weekly newspaper Feral Tribune were made with photomontage, and the motif of barbed wire was also used - the cover of the number that deals with the fleeing camp commandant is entirely crisscrossed with horizontal lines of barbed wire (cf. image in Pavelić 423).

[11] The terms blended and input space are used as per the theory of conceptual integration (cf. Fauconnier and Turner).

[12] Pamela Anderson, who had in the TV series created the stereotype of a blond girl in a red swimming suit, is also the protagonist of the SF film Barb Wire, based on a comic book about an anti-heroine (aka Barbara Kopetski) in the Dark Horse Universe. The film did not particularly attract attention, since it, among other things, "failed to fully embrace the feminist essence of Barb Wire, starting with the miscasting of Pamela Anderson in the leading role" (Dixon and Graham 67).

[13] The song's refrain is: Ti si savršenstvo bez maneti si deo vojničkih snovati si lutka sa naslovne stranei treba ti lova.(as per the audio file at: www.youtube.com/watch?v=T6z7izNI9BM, accessed on 15 September 2020)[You are perfection without a flaw | You are a part of soldiers' dreams | You 
are a doll from the cover | And you need money]The eponymous song from 1985 by the band Zabranjeno pušenje is less known: Htjela si da tvoje aktove Vidi barem pola svijeta A sada u granapu Sedrenika Lokalni dripci te pitaju Lutko, pošto je pašteta(as per the audio file at: www.youtube.com/watch?v=u147LwSzR7g, accessed on 15 September 2020)[You wanted your act / To be seen by at least half of the world / And now at Sedrenik's grocery store / Local punks ask you / Doll, how much is the pâté]

[14] On the cultural model of seeing and the conceptual metaphor to know is to see cf. Stanojević.

[15] ... Za ovu zemlju sve vas, sve vas veže: - Ime i jezik, bratstvo, i krv sveta! ...Ostajte ovdje! Sunce tuđeg nebaNeće vas grijat k'o što ovo grije!Grki su tamo zalogaji hljebaGdje svoga nema i gdje brata nije... (A. Šantić, "Ostajte ovdje...", Šantić 32).[... To this land everything, everything ties you: | Name and language, brotherhood, and holy blood. | Stay here!... | The sun of a foreign sky | Will not warm you as this one does, | Bitter are the bites of bread there | Where your own is not present and neither is your brother...]

[16] Musolff (2014) considers the universal body-politic metaphor as a copy of the hierarchy of upper and lower body parts, of the ruler's head and the subjects' extremities.

[17] The sea expanse and the archetype of smooth space is generally the first space to be subjected to striation that gradually conquered it, either through state parcellation or navigation technology (cf. Deleuze and Guattari 545).

[18] A text by Viktor Ivančić published in Feral in 1999, questioning the Western ideology of "false responsibility" regarding the military interventions in the Balkans, had the same title (cf. www.v6.infobiro.ba/article/606883).

\section{(c) (i) (9)}

Creative Commons Attribution-NonCommercial-NoDerivatives 4.0 International License 